\title{
Formulation, Optimization, and In-Vitro Evaluation of Hyaluronic Acid Buccal Films Containing Benzydamine Hydrochloride
}

\author{
Alptug KARAKUCUK [i] $^{1,2}$, Serdar TORT 國 1
}

\begin{abstract}
Aim: Mucoadhesive buccal films provide drug delivery for both local and systemic circulation with increased patient compliance. The objective of this study was to develop a buccal film containing benzydamine hydrochloride (BNZ) by using hyaluronic acid (HA) as a film-forming agent and glycerin (Gly) as a plasticizer for the anti-inflammatory effect on the mucosal ulcer.

Material and Methods: The effects of different concentrations of HA and Gly on responses were analyzed using $2^{3}$ factorial design. The HA and Gly ratio were selected as independent factors, and work of mucoadhesion, tensile strength, elongation at break, and contact angle values were chosen as dependent factors. Nine different film formulations were prepared at constant BNZ concentration $(0.15 \%)$ by solvent casting method. Mechanical and mucoadhesion properties of film formulations were evaluated, and also contact angles were calculated. The BNZ release profiles were evaluated in simulated saliva solution ( $\mathrm{pH}$ 6.8).

Results: All film formulations were successfully prepared by solvent casting method. Increasing HA concentration from 0.5 to $2 \%$ raised the mechanical and mucoadhesion properties of film formulations. Although the addition of Gly decreased the tensile strength values, it increased the elongation at break values about ten times. All formulations released more than $60 \%$ BNZ in 60 mins.

Conclusion: It is concluded that HA oral mucoadhesive film formulations containing BNZ are promising for treating oral ulcers.
\end{abstract}

Keywords: Benzydamine hydrochloride; hyaluronic acid; buccal film; solvent casting method.

\section{Benzidamin Hidroklorür İçeren Hyaluronik Asit Bukkal Filmlerinin Formülasyon, Optimizasyon ve İn-Vitro Değerlendirilmesi}

\section{Öz}

Amaç: Mukoadezif bukkal filmler, artmış hasta uyumu ile hem lokal hem de sistemik dolaşıma ilaç geçişini sağlayan sistemlerdir. $\mathrm{Bu}$ çalışmanın amacı, mukozal ülser üzerindeki antiinflamatuvar etki için film oluşturucu ajan olarak hyaluronik asit (HA) ve plastizer olarak gliserin (Gly) kullanarak benzidamin hidroklorür (BNZ) içeren bukkal film geliştirmektir.

Gereç ve Yöntemler: Farklı HA ve Gly konsantrasyonlarının etkisi $2^{3}$ faktöryel tasarım kullanılarak analiz edilmiştir. HA ve Gly oranı bağımsız faktörler seçildi ve mukoadezyon, gerilme kuvveti, kopmada uzama ve temas açısı değerleri bağımlı faktörler olarak seçildi. Dokuz farklı film formülasyonu çözücü dökme yöntemi ile sabit BNZ konsantrasyonunda $(\% 0,15)$ hazırlandı. Film formülasyonlarının mekanik, mukoadezyon özellikleri değerlendirildi ve temas açıları hesaplandı. BNZ salım profilleri, yapay tükrük çözeltisinde $(\mathrm{pH}$ 6.8) gerçekleştirildi.

Bulgular: Film formülasyonlarının hepsi çözücü dökme yöntemi ile başarıyla hazırlanmıştır. HA konsantrasyonunun \% 0,5'ten \%2'ye yükseltilmesi, film formülasyonlarının mekanik ve mukoadezif özelliklerini artırmıştır. Gly ilavesi kopma gerilim değerlerini düşürmesine rağmen kopma uzaması değerlerini yaklaşık 10 kat arttırmıştır. Tüm formülasyonlar 60 dakikada \% 60'tan fazla BNZ salmıștır.

Sonuç: BNZ içeren HA oral mukoadezif filmlerin oral ülserlerin tedavisi için umut verici bir formülasyon olduğu 
sonucuna varılmıștır.

Anahtar Kelimeler: Benzidamin hidroklorür; hyaluronik asit; bukkal film; çözücü dökme yöntemi.

\section{INTRODUCTION}

Oral ulcers are formed due to epithelial damage or specific causes as trauma, hypersensitivity, malignancy, and chemotherapy (1). The typical approach for the treatment of oral ulcers is topical applications. Patches and films are widely used for drug delivery to oral ulcers of the oral cavity, characterized by painful ulceration of the oral mucosa (2).

Oral films bring benefits for the patients who have difficulties with swallowing (3). One of the oral films is the buccal film which delivers drug compounds through the oral mucosa. They are defined as "single-or multilayer sheets that adhere to the buccal mucosa and may dissolve" in the European Pharmacopeia (4). They may be preferred over conventional dosage forms in regards to flexibility and comfort. They also can easily be washed away by saliva and protect the wound surface, which reduces the pain (5). Other advantages of buccal films include controlled drug delivery, avoidance of hepatic first-pass effect, large absorption surface, and simple delivery devices (6).

Mucoadhesive buccal films are prepared by the solvent casting method. In this method, a film-forming polymer is dispersed in a solvent, and the solution is cast on a flat surface. The laminar hot-melt extrusion technique can also use to produce buccal films. The film's mechanical properties were affected by the type and amount of the film-forming polymer, active compound and plasticizer, residual solvents, and manufacturing process (7). Plasticizer affects tensile strength and elongation of the films, and it helps to improve the flexibility of the film formulation. Various agents such as glycerin, sorbitol, propylene glycol, polyethylene glycol, dibutyl phthalate, or citrate esters can be used as a plasticizer at a concentration between $0-20 \%$ (8).

Benzydamine hydrochloride (BNZ) is a non-steroidal compound, which affects topical anti-inflammatory, analgesic, anesthetic, and antimicrobial effects on oral ulcers (2). Oral, topical, and mucosal dosage alternatives are currently available for BNZ in the market. It is used for the anti-inflammation effect on the oral cavity at a concentration of $0.15 \%$ (9). BNZ has rare adverse effects, which include numbness and mucosal irritation (10).

Hyaluronic acid (HA) is a biodegradable, biocompatible, non-immunogenic, and mucoadhesive linear polysaccharide of D-glucuronic acid and N-acetyl-Dglucosamine (11-13). It provides tissue healing for oral ulcers by activating the inflammatory responses, promoting cell growth, and re-epithelization (14).

The objective of the current study was to develop a buccal film containing BNZ as an active compound. The buccal films were produced by solvent casting method by using HA as a film-forming polymer. The combination use of HA with non-steroid anti-inflammatory drugs (NSAIDs), in this case, BNZ, can bring benefits for the fast relief and healing for oral ulceration (11). The glycerin (Gly) was used as a plasticizer if necessary. The formulation design was generated, and in-vitro characterization, bioadhesion, and in vitro drug release studies were performed.

\section{MATERIAL AND METHODS \\ Materials}

Benzydamine hydrochloride was provided from Abdi Ibrahim Pharmaceuticals. Hyaluronic acid (400 kDa) was purchased from Kadığlu Medikal (Ankara, Turkey). Gly was purchased from Sigma Aldrich. All other chemicals were analytical grade.

\section{Preparation of BNZ mucoadhesive buccal film formulations}

BNZ mucoadhesive buccal films were prepared by using the solvent casting method. Firstly, different amounts of HA $(0.5,1,2 \%)$ were dissolved in distilled water at room temperature under mechanical mixing (Eurostar 20 equipped with R1302 dissolver stirrer, IKA) for $3 \mathrm{~h}$. Then, $0.15 \%$ BNZ was dissolved in the HA gel, and 0, 1, or $2 \%$ of Gly was added directly as the plasticizer. Nine different film formulations were prepared (Table 1).

Table 1. Different concentrations of HA, Gly and BNZ used in BNZ film formulations

\begin{tabular}{|c|c|c|c|}
\hline Formulation code & HA & Gly & BNZ \\
$(\%)$ & $(\%)$ & $(\%)$ \\
\hline F1 & 0.5 & 0 & 0.15 \\
\hline F2 & 0.5 & 1 & 0.15 \\
\hline F3 & 0.5 & 2 & 0.15 \\
\hline F4 & 1 & 0 & 0.15 \\
\hline F5 & 1 & 1 & 0.15 \\
\hline F6 & 1 & 2 & 0.15 \\
\hline F7 & 2 & 0 & 0.15 \\
\hline F8 & 2 & 1 & 0.15 \\
\hline F9 & 2 & 2 & 0.15 \\
\hline
\end{tabular}

Finally, $15 \mathrm{~g}$ of the gel was poured into a plastic petri dish (diameter $9 \mathrm{~cm}$ ), and the solvent was left to evaporate at room temperature in a fume hood for $48 \mathrm{~h}$. The dried films were cut with stainless-steel punch before the analysis. 23- the factorial design was generated with independent factors, which were HA and Gly ratio, and dependent factors, which were work of bioadhesion, tensile strength, elongation at break, and contact angle values. The amount of BNZ used in buccal films was chosen as $0.15 \%$, which is the same amount in commercial products. It was intended to develop buccal films. Therefore the desired target attributed levels were specified as suitable bioadhesion and mechanical properties, $<90^{\circ}$ of contact angle and $80 \% \mathrm{BNZ}$ release in 60 minutes as the quality target product profile. Gly and HA amounts differ in literature data, and the concentrations were selected regarding pre-studies. 
Experiments were performed randomized with two replicates. Data were analyzed by using Design Expert ${ }^{\circledR}$ Version 9.

\section{Scanning Electron Microscopy (SEM) studies}

The morphologies of BNZ mucoadhesive film formulations were analyzed with SEM images. SEM images of films were collected using a scanning electron microscope (Thermo Scientific Quattro S). Images were captured at $15 \mathrm{kV}$ with different magnifications under high vacuum conditions.

\section{Characterization studies of BNZ mucoadhesive buccal} film formulations

Mechanical and mucoadhesive performance of BNZ mucoadhesive film formulations were evaluated using a Texture Analyzer. Tensile strength and elongation at break values were analyzed in terms of mechanical properties. The buccal tissue of sheep is fixed on the base of the heavy-duty platform. Film formulation was fixed to the lower end of the probe. The buccal tissue was wetted with saline prior to the experiment. The probe was contacted with the buccal tissue for $120 \mathrm{~s}$ with an applied force of $0.2 \mathrm{~N}$ and the rate of $1 \mathrm{~mm} / \mathrm{s}$. The area under force $(\mathrm{N})$-distance $(\mathrm{mm})$ curve was calculated using the device's software, and the work of mucoadhesion was measured. All measurements were triplicated. For the determination of the mechanical properties, mini tensile grip apparatus was used. Film formulations were cut with a shape of $3 \times 1 \mathrm{~cm}$. The deformation area was fixed as $1 \times 1 \mathrm{~cm}$.

The hydrophilicity/hydrophobicity of film formulations were evaluated with an optical tensiometer (Attension

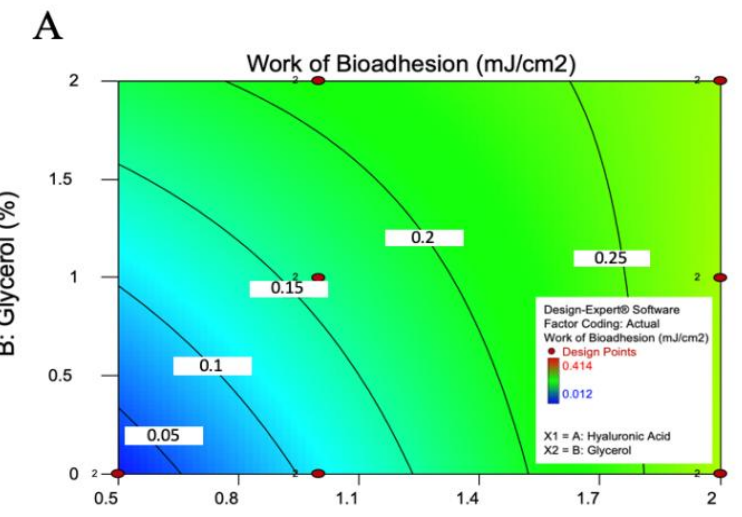

A: Hyaluronic Acid (\%)

$$
\text { C }
$$

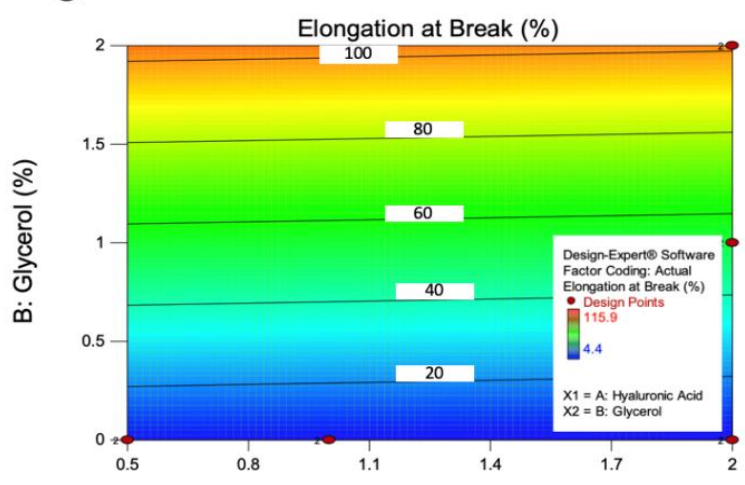

A: Hyaluronic Acid (\%)
Theta Lite, Biolin Scientific, Finland). For this purpose, 5 $\mu \mathrm{L}$ distilled water was dropped on a film surface. Then, the contact angle of the droplet on the film was calculated by using the OneAttension software.

\section{Release studies of mucoadhesive buccal film} formulations

Release studies were adapted from an in vitro dissolution method for sublingual tablets (15). For this purpose, BNZ from film formulations was placed in $2 \mathrm{~mL}$ of simulated saliva solution ( $\mathrm{pH} 6.8)$ as a dissolution medium at $37^{\circ} \mathrm{C}$. At predetermined time points $(5,10,15,30,60 \mathrm{~min})$, a 10 $\mu \mathrm{L}$ sample was withdrawn, and a buffer solution with the same volume was added. BNZ concentration in the sample was determined using a small volume spectrophotometer at $305 \mathrm{~nm}$ (BioSpec Nano, Shimadzu). The drug concentration was calculated from the calibration curve, which was determined with the absorbances of the prepared standard dilutions.

\section{RESULTS}

In this study, $0.5,1$, and $2 \%$ concentrations of HA were selected for film-forming. 0,1 and $2 \%$ concentrations of Gly were used as plasticizer due to its safety in oral mucosal treatments.

The effects of different concentrations of HA and Gly on responses were analyzed by using $2^{3}$ factorial design. Contour graphs were generated to evaluate the results (Figure 1). Two-way interaction between the concentration of Gly and concentration of HA was found significant for the work of bioadhesion results (Figure 1).
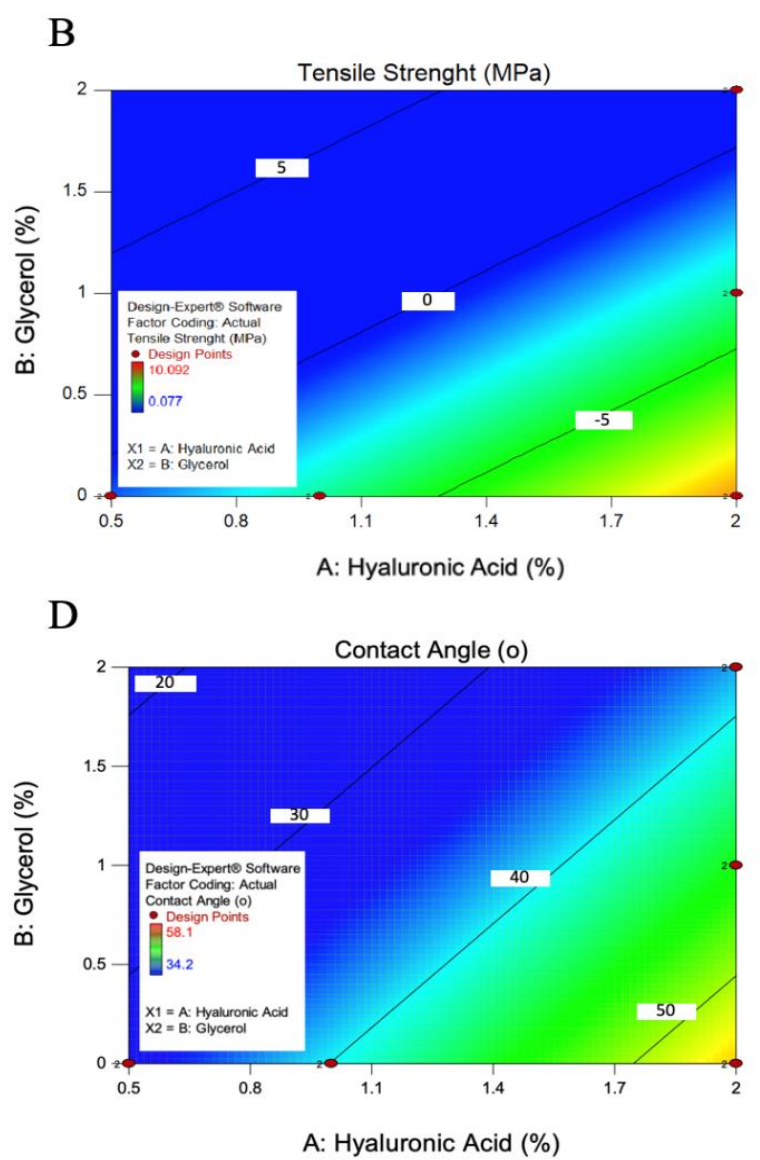

Figure 1. Contour plots of responses showing the effect of the hyaluronic acid and glycerol. A- work of bioadhesion, Btensile strength, C- elongation at break, D- contact angle 
The increased bioadhesion values were observed while using the higher level of HA. This may be due to obtaining higher surface area by increasing polymer concentration (14).
SEM images showed that increasing Gly concentration from 0 to $2 \%$ caused some cracks and defects on the film surface. F7 formulation had crack-free morphology compared to F8 and F9 formulations (Figure 2).

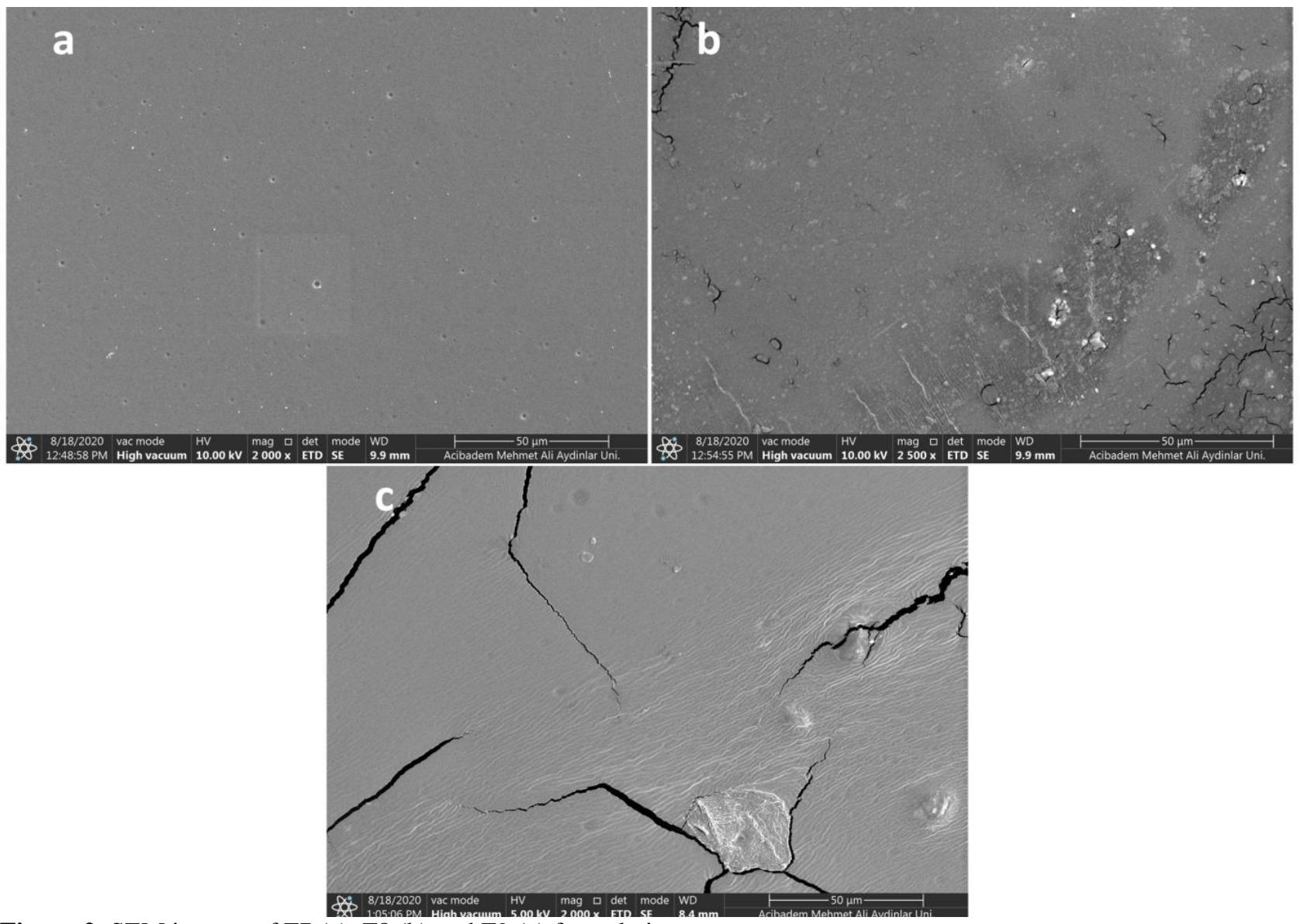

Figure 2. SEM images of F7 (a), F8 (b) and F9 (c) formulations

In-vitro release studies were evaluated in two groups: the effect of HA without glycerin (F1, F4, F7) and glycerin at 2\% HA (F7, F8, F9) concentrations. Both F1 and F4 formulations showed a burst release and released more than $80 \%$ drug in 5 minutes (Figure 3). The release profiles of $\mathrm{F} 1$ and $\mathrm{F} 4$ were found to be similar. As expected, increasing $\mathrm{HA}$ at $2 \%$ concentration decreased the $\mathrm{BNZ}$ release.

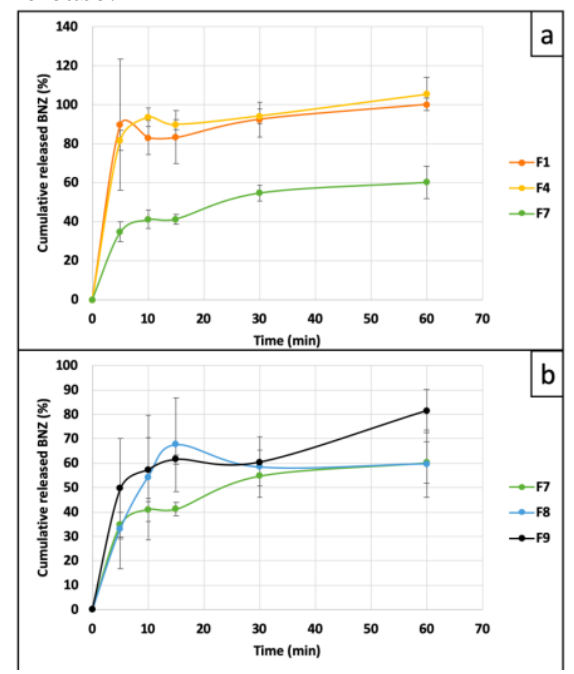

Figure 3. In vitro release profiles of formulations

\section{DISCUSSION}

BNZ is a commonly used active substance in oral or pharyngeal ulceration treatment. A combination of BNZ with chlorhexidine gluconate is an alternative against topical steroids (16). It is freely soluble in water and primarily used in mouthwash formulations. HA, which can be found in some tissues, has ulcer healing effects due to its anti-inflammatory properties. In addition to its pharmacological wound healing activity, it has superior film-forming properties (17). Although the high molecular weight of HA $(>300 \mathrm{kDa})$ improves the filmforming property, the low molecular weight of HA $(<300$ $\mathrm{kDa}$ ) is more successful in terms of skin penetration (18). The bioadhesion is a crucial factor for buccal films that affect therapeutic effect for prolonged periods (19). It is seen that using above $1.5 \%$ of HA with $2 \%$ of Gly resulted in higher work of bioadhesion results (Figure 1A). Linear models were used for tensile strength, elongation at break, and contact angle (Figure 1B-D). The tensile strength and elongation of break parameters are about the strength and elasticity of the film. The maximum stress applied to the part of the film is measured at which the film breaks for tensile strength. The ratio of increased length of the film to original length is calculated for elongation at break. Using a higher 
concentration of plasticizer resulted in lower tensile strength values, which is compatible with literature (20). Hydrophilicity and wettability of the films were evaluated by contact angle measurements. Higher HA concentration resulted in a higher contact angle up to $50^{\circ}$. Increasing Gly concentration provided a narrower angle of contact. Hence, Gly concentration improves the hydrophilic property of HA films.

HA concentration directly affects mechanical properties. Film formulations without Gly had the highest tensile strength values due to their rigid structure. The addition of Gly softened the film formulations, which is obvious according to tensile strength values. Tensile strength values of F7 formulation without Gly decreased dramatically from $10 \mathrm{MPa}$ to below $0.1 \mathrm{MPa}$ by the addition of Gly. In contrast, Gly addition increased the elongation at break values. Like our results, Salehi and Boddohi found higher elongation at break values after the addition of glycerin to rizatriptan-loaded film formulations (21).

It was observed that $2 \% \mathrm{HA}$ created a controlled release matrix due to its swelling property. Similarly, Pornpitchanarong et al. (22) formulated that clotrimazole loaded hyaluronic acid-catechol/polyvinyl alcohol mucoadhesive films and found the complete release was obtained at $6 \mathrm{~h}$. Sonvico et al. (23) prepared cisplatinloaded sodium hyaluronate films and observed more than $90 \%$ of the drug release in three hours. Following the mechanical properties, the addition of glycerin to the film formulation weakened the structural integrity. The addition of glycerin to the F7 formulation fastened the drug release from film formulation.

In this study, BNZ containing HA film formulations were formulated and produced successfully. $\mathrm{HA}$ at $2 \%$ concentration provided stronger mechanical and higher mucoadhesion properties compared to 0.5 and $1 \%$ concentrations. F9 formulation ( $2 \% \mathrm{HA}$ and $2 \% \mathrm{Gly}$ ) released $80 \%$ of $\mathrm{BNZ}$ in $60 \mathrm{~min}$, which was successful for the buccal route. BNZ containing HA film formulations could be an alternative therapy for oral ulcer patients.

Authors's Contributions: Idea/Concept: A.K., S.T.; Design: A.K., S.T.; Data Collection and/or Processing: A.K., S.T.; Analysis and/or Interpretation: A.K.; Literature Review: A.K., S.T.; Writing the Article: A.K., S.T.; Critical Review: S.T.

\section{REFERENCES}

1. Alves TFR, Rios AC, Pontes K da S, Portella DL, Aranha N, Severino P, et al. Bilayer mucoadhesive buccal film for mucosal ulcers treatment: development, characterization, and single study case. Pharmaceutics. 2020; 12(7): 1-24.

2. Yaprak Karavana S, Güneri P, Ertan G. Benzydamine hydrochloride buccal bioadhesive gels designed for oral ulcers: preparation, rheological, textural, mucoadhesive and release properties. Pharm Dev Technol. 2009; 14(6): 623-31.

3. Pechova V, Gajdziok J, Muselik J, Vetchy D. Development of orodispersible films containing benzydamine hydrochloride using a modified solvent casting method. AAPS Pharm Sci Tech. 2018; 19(6): 2509-18.

4. Borges AF, Silva C, Coelho JFJ, Simoes S. Oral films: Current status and future perspectives: Igalenical development and quality attributes. J Control Release. 2015; 206: 1-19.

5. Semalty M, Semalty A, Kumar G. Formulation and characterization of mucoadhesive buccal films of glipizide. Indian J Pharm Sci. 2008; 70(1): 43-8.

6. Nappinnai M, Chandanbala R, Balaijirajan R. Formulation and evaluation of nitrendipine buccal films. Indian J Pharm Sci. 2008; 70(5): 631-5.

7. Preis M, Knop K, Breitkreutz J. Mechanical strength test for orodispersible and buccal films. Int J Pharm. 2014; 461(1-2): 22-9.

8. Mahajan A, Chhabra N, Aggarwal G. Formulation and characterization of fast dissolving buccal films: a review. Der Pharm Lett. 2011; 3(1): 152-65.

9. Akbal O, Cevher E, Araman AO. The development and in vitro evaluation of benzydamine hydrochloride medicated chewing gum formulations. Istanbul J Pharm. 2017; 47(2): 45-51.

10. Khabazian A, Tavakoli A, Soltani S, Karami E, Mohaghegh N. Comparison of benzydamine hydrochloride mouthwash $0.15 \%$ and 1 buprofen in reducing postoperative pain during 24 hours after crown lengthening: a randomized clinical trial. Open Dent J. 2020; 14(1): 66-70.

11. Carvalho JPF, Silva ACQ, Bastos V, Oliveira H, Pinto RJB, Silvestre AJD, et al. Nanocellulose-based patches loaded with hyaluronic acid and diclofenac towards aphthous stomatitis treatment. Nanomaterials. 2020; 10(4): 628 .

12. Kim S, Cho DH, Kweon DK, Jang EH, Hong JY, Lim ST. Improvement of mechanical properties of orodispersible hyaluronic acid film by carboxymethyl cellulose addition. Food Sci Biotechnol. 2020; 29(9): 1233-9.

13. Necas J, Bartosikova L, Brauner P, Kolar J. Hyaluronic acid (hyaluronan): a review. Vet Med. 2008; 53(8): 397-411.

14. Abo-shady AZ, Elkammar H, Elwazzan VS, Nasr M. Formulation and clinical evaluation of mucoadhesive buccal films containing hyaluronic acid for treatment of aphthous ulcer. J Drug Deliv Sci Technol. 2020; 55: 101442 .

15. Rachid O, Rawas-Qalaji M, Simons FER, Simons KJ. Dissolution testing of sublingual tablets: a novel in vitro method. AAPS PharmSciTech. 2011; 12(2): 544-52.

16. Casale M, Moffa A, Vella P, Rinaldi V, Lopez MA, Grimaldi V, et al. Systematic review: the efficacy of topical hyaluronic acid on oral ulcers. J Biol Regul Homeost Agents. 2017; 31(4-S2): 63-9.

17. Graça MFP, Miguel SP, Cabral CSD, Correia IJ. Hyaluronic acid-based wound dressings: a review. Carbohydr Polym. 2020; 241: 116364.

18. Essendoubi M, Gobinet C, Reynaud R, Angiboust JF, Manfait M, Piot O. Human skin penetration of hyaluronic acid of different molecular weights as probed by Raman spectroscopy. Skin Res Technol. 2016; 22(1); 55-62. 
19. Okonogi S, Khongkhunthian S, Jaturasitha S. Development of mucoadhesive buccal films from rice for pharmaceutical delivery systems. Drug Discov Ther. 2014; 8(6): 262-7.

20. Rajput G, Majmudar F, Patel J. Formulation and evaluation of mucoadhesive glipizide films. Acta Pharm. 2011; 61(2): 203-16.

21. Salehi S, Boddohi S. New formulation and approach for mucoadhesive buccal film of rizatriptan benzoate. Prog Biomater. 2017; 6(4): 175-87.

22. Pornpitchanarong C, Rojanarata T, Opanasopit P, Ngawhirunpat, T, Patrojanasophon P. Clotrimazole nanosuspensions-loaded hyaluronic acidcatechol/polyvinyl alcohol mucoadhesive films for oral candidiasis treatment. J Drug Deliv Sci Technol. 2020; 60: 101927.

23. Sonvico F, Barbieri S, Colombo P, Mucchino C, Barocelli E, Cantoni AM, et al. Physicochemical and pharmacokinetic properties of polymeric films loaded with cisplatin for the treatment of malignant pleural mesothelioma. J Thorac Dis. 2018; 10(S2): S194-206. 